\title{
Location of Industry in Great Britain*
}

\begin{abstract}
$\mathrm{T}$ HE report on the location of industry which has now been issued by Political and Economic Planning (P E P) is one of a series of contributions to this subject which has been made by $\mathrm{P}$ E $\mathbf{P}$ since, in April 1935, it was decided to undertake a comprehensive study of regional development to provide a sound basis for the evolution of policy. Apart altogether from its recommendations, this report contains much that is new and gives by far the most comprehensive and scientific survey yet available of a problem which many factors besides those of the Special Areas and defence policy are forcing upon our attention.
\end{abstract}

After reviewing briefly the factors which led to the emergence of the problem, the report, by means of a series of diagrams, shows the recent changes in British industry and its present distribution by regions. The employment chart for all insured persons, including distributive and other workers, shows how, between 1923 and 1937, the south-east, Greater London, the south-west and the Midlands increased their proportion of total national employment at the expense of other regions, particularly Wales and the North. Since 1921, some 700,000 persons from other parts of Great Britain have migrated to Greater London. The net output figures show similar changes, with Greater London rising by nearly 50 per cent between 1924 and 1935 and South Wales declining almost as sharply. In 1935, Greater London had more workers actually employed than any other region, and at the same time a higher value of net output per head. Apart from their heavier burden of unemployment, the older industrial regions of the north-east, the West Riding and Lancashire have markedly lower net outputs per head than the southeast and east England or the Midlands. Between 1927 and 1937, the extractive group of industries reduced its use of labour by more than 30 per cent, textiles and elothing by 20 per cent, while heavy industry also slightly declined, but light and intermediate industries, building, transport, distribution and services expanded their personnel.

The region with fewest types of industry is south Scotland, in which 39 per cent of British industries are virtually unrepresented and a further 36 per cent have location factors below $0 \cdot 45$. Lancashire and Cheshire show most types of industry, while the West Midlands have the largest share of industrial concentration, nearly 20 per cent of their industries having location factors greater than 2. Between 1924 and 1935, Greater London maintained or in. creased its relative share of output in all industrial groups except two, and even in these its net output increased. Nevertheless, London is now getting no more than its proportionate share of new employment. In the last six years, the south-east and Midland divisions have made most advance, but the northern division has recovered nearly a third of the ground previously lost. Scotland, Wales and the north-east have held their own, the north-west continuing to lose heavily. The four southern divisions

*Report on the Location of Industry : a Survey of Present Trends in Great Britain affecting Industrial Location and Regional Economic 1939.) 1.0s. 6 d. net. now claim nearly 54 per cent of British employed workers as against less than 47 per cent in 1923, and London's employed population is now nearly half as high again as sixteen years ago.

Changes in employment in individual industries are also discussed, and the report then considers the factors which have determined the location of industries, including some discussion of the finance of new developments. A close survey of existing trading estates follows, while an analysis of the effects of the location of industry points out that about 43,000 acres of land are taken from the farmer annually by industry, while at the same time the State has to spend large sums on cleaning up sites abandoned by industry in a derelict and unusable condition. Residential and university towns have their amenities ruined by new mushroom industries, while towns built for industry stand halfidle. This analysis of social effects is followed by a discussion of the different types of town in relation to industry, an analysis of the main considerations affecting industry and defence, of the need for balanced regional development and a discussion of the aims of national industrial policy.

The final chapter of the report outlines its proposals to meet the main needs not covered by existing machinery-the provision of a centralized research and information service and the effective co-ordination of action. The main proposal is the creation of a permanent Industrial Development Commission to guide the location of industry and advise the Government on the subject. The Commission would be charged with the licensing of new factories or extensions; where a licence was refused, it would be required to indicate broadly the areas and categories of industry in respect of which applications would not in principle be favoured. It would keep under review all factors affecting the efficient operation of industry or affecting economic development of different areas and the location of industry. Like the Commissioners for the Special Areas, it would have resources for giving limited financial help to overcome obstacles to industrial development in specific instances. The Commission would explore the problem of financing new enterprise, would take over the responsibility for supervising existing publicly owned trading estates and for the preservation or restoration of amenities.

The report also suggests that the Commission should take over the machinery for the Special Areas and, particularly, that it should consider the problems of evacuation and re-settlement where necessary. Using Merthyr as an example, it is suggested that transfer as a community of such a town of 63,000 inhabitants at a total cost of $£ 15$ millions would represent a total cost to the State in interest and sinking fund of less than the $£ 832,000$ actually paid out in 1937-38 to keep much of Merthyr in idleness. It is proposed that the Commission should be responsible to Parliament through a senior Cabinet Minister without departmental duties, and its probable cost need not exceed that of the Special Areas Commissioners, whom the new industrial body would in time supersede. 